Vol. 02, No. 1, January 2018, 73-96

Avalaible at: https://ojs.unud.ac.id/index.php/UJLC/issue/view/2675 E-ISSN 2549-0680

\title{
Human Rights and the Environmental Protection: The Naïveté in Environmental Culture
}

\author{
Made Adhitya Anggriawan Wisadha* \\ Centre for International Law and Human Rights \\ and Richardson Institute Lancaster University, United Kingdom
}

\section{Grita Anindarini Widyaningsih**}

University of Aberdeen, United Kingdom

\begin{abstract}
There are growing trends in the human rights to substantially extend the values to protect the environment or moreover to welcome the ideas of the rights to environment, not to mention the rights of environment. The purpose is to inclusively embrace the environmental problems wherein the humanity challenges posited on, but this agenda may leave a room of doubt how far the human rights body can address the environmental destruction as it needs the interplay of culture and environmental ethics to promoting such concepts. Therefore, this paper aims to identify the justification of how human rights in the environmental protection in the contemporary discourse are bringing to light, as many current cases attempt to linkage the environmental approach to the human rights instrument, such as the rights to life, healthy environment, and intergenerational equity. To analyse further, the theoretical framework in this paper will be explicated by environmental culture paradigm which illustrates the egalitarian concept between human and environment to elicit the clear thoughts of how human rights is naïve to protect the environment. This article will firstly depict the human rights and the environmental protection discourse and then, explore the naïvete narratives of environmental culture about the ecological crisis roots that are fundamentally anthropogenic, as to reflect the ground realities how this nexus will play out. Finally, this paper found the moral justification per se relies on the effort of elaborating the human prudence in their relationship with nature, albeit bringing the naïveté.
\end{abstract}

Keywords: Environmental Culture, Environmental Protection, Human Rights, Naïveté.

How to Cite (chicago-16th): Anggriawan Wisadha, Made Adhitya, and Grita Anindarini Widyaningsih. "Human Rights and the Environmental Protection: The Naïveté in Environmental Culture." Udayana Journal of Law and Culture 2, no. 1 (2018): 73-96. https://doi.org/10.24843/ UJLC.2018.v02.i01.p04.

DOI: https://doi.org/10.24843/UJLC.2018.v02.i01.p04

\section{Introduction}

"A weakened sense of the reality of our embeddedness in nature is seen in the cultural phenomenon of ecological denial which refuses to admit the reality and seriousness of the ecological crisis."

\footnotetext{
* Email/Corresponding Author: m.anggriawan@lancaster.ac.uk

** Email: g.widyaningsih.17@aberdeen.ac.uk

1 Val Plumwood. Environmental Culture: The Ecological Crisis of Reason, 1st ed. (New York: Routledge,
} 2002), 97 
It is an exhaustive contention that every social problem will necessarily ensue human rights claims ${ }^{2}$ included the environmental problem that is inherently related to human livelihood. This insemination of human rights claims on environmental discourse arguably departs from Stockholm in 1972, United Nations (UN) Conference on the Human Environment which stated that every people have fundamental rights to freedom, equality, and adequate conditions in their environment who entitled them such life dignity and prosperity. ${ }^{3}$ This critically express the roles of human rights to protect human livelihood which later strengthened by the Principle 3 of Rio Declaration on Environment and Development wherein concerned on sustainable meaning that the interdependence between human needs and environment entwined, "The right to development must be fulfilled so as to equitably meet developmental and environmental needs of present and future generations"4

However, it can be seen perspicuously that these instruments rather put forward anthropogenic approach than the ecological-centric ${ }^{5}$ or in the nexus of the two crucial points, as this supported literally by Principle 1 of Rio Declaration justified that human being is the salient points of such concern. However, the clear effort to identify the relationship between the human rights and the environment progressively appropriated by the United

Nations Human Rights Council. ${ }^{6}$ Which later on, the independent working group led by the Special Rapporteur John Knox, to deeply observe the human rights obligations relating to the enjoyment of a safe, clean, healthy and sustainable environment. ${ }^{7}$ According to the report of the independent group, there is the environmental obligation arising from substantive human rights, such as the rights to a healthy environment as the prerequisite to the full enjoyment of human rights itself. ${ }^{8}$ This rapid development is understandable due to the upsurge human rights cases that pertain to the environmental problems in global context, such as from the largescale pollution EHP $v$. Canada in 1945 to $1952,{ }^{9}$ individual case of Öneryildizv. Turkey in European Court of Human Rights about the exposure of dangerous industrial activities, ${ }^{10}$ Maya Indigenous Community of the Toledo District $v$. Belize (2004) in

2 Asbjørn Eide and Jan Helgesen, The Future of Human Rights Protection in A Changing World: Fifty years of the Four Freedoms Address, (Oslo: Norwegian University Press, 1991), 196.

3 United Nations, Report of the United Nations Conference on the Human Environment, A/ CONF.48/14/Rev.1, available from www.un-documents.net/aconf48-14r1.pdf, principle 1.

4 Declaration on Sustainable and Environment, Rio de Janeiro 3-14 June 1992, Report of the United Nations Conference on Environment and Development, A/CONF.151/26, vol.1, principle 3.

5 Paolo Galizzi, "From Stockholm to New York, via Rio and Johannesburg: Has the Environment Lost Its Way on the Global Agenda”, Fordham Int'l L.J. 29, no. 5 (2005): 956.

6 United Nations Human Rights Council (UNHRC) res. 16/11, 'Human Rights and the Environment'. 24 Mar. 2011.

7 UNHRC res. 19/12. 'Human Rights and the Environment'. 20 Mar. 2012.

8 United Nations Independent Expert on Human Rights and the Environment with the Office of the High Commissioner for Human Rights 21-22 June 2013.

9 EHP v Canada (Communication No. 67/1980) (1982) 33.

10 Öneryıld1z v Turkey, App no 48939/99, ECHR 2004-XII, (2005). 
Inter-American Court of Human Rights (IACHR) Case about the communal property and land, ${ }^{11}$ or more recently, the Philippines Commission on Human Rights sent an amicus curiae brief to the domestic court of Philippines to requesting for investigation major carbon polluters companies for their human rights violation regarding human-induced climate change. ${ }^{12}$ These cases arguably involved the States as well as the private companies to be held accountable for any cause of the environmental damage.

Why this becomes a crucial topic? As Alan Boyle argued that the human rights bodies may lift up 'the standard of environmental quality based on the states obligation to take measures to control the pollution affecting health and life. ${ }^{13}$ This discourse is increasingly discussed in general human rights law. Therefore, the idea of 'greening' mainstream human rights urgently demanded as environmental rights caseload in human rights courts recently multiplied. ${ }^{14}$ However, what is lack of this mainstream idea is the integrity of human 'natural' rights discourse itself in the context of environmental culture, ${ }^{15}$ as Steven J. Hood argued that promoting the human rights may be successful if applying the "conscious cultural learning'16 so that we shall thus find the moral justification of how human rights in the environmental claims in the contemporary discourse are bringing to light. Meaning that it withdraws from a rationale inquiry about the environmental rights and the rights to environment, what are the rights actually for? To answer this, the narrative can be surreptitious to boiling down to the mere human entitlements instead of unfolding the human self-enclosure as part of ecological beings to preserve the intrinsic environmental values. ${ }^{17}$

This article, therefore, attempts to view a major complication of human rights in environmental protection ideas while human is 'hero, villain, and victim"18 in the same time of environmental problems. Also, the consequences of mainstreaming the environment protection into the existing corpus of human rights law can be futile, if this embodiment is not rarefying its justification first then postulate the legal architecture. Not to mention the hardship it may suffer when examining the paradigm

11 Maya indigenous community of the Toledo District v. Belize, Case 12.053, Report No. 40/04, Inter-Am. C.H.R., OEA/Ser.L/V/II.122 Doc. 5 rev. 1 at 727 (2004).

12 James E. Hansen, 'Amicus Curiae Brief Petition Requesting for Investigation of the Responsibility of the Carbon Majors for Human Rights Violations or Threats of Violations Resulting from the Impacts of Climate Change, Commissioners, Commission on Human Rights of the Philippines' published on 16th December 2016, https:/ / business-humanrights.org/sites/default/files/documents/2017.08.28_Jim.Hansen.Amicus_Comm_Human\%20Rights_0.pdf accessed on 12 February 2018.

13 Alan Boyle, 'Human Rights and the Environment: Where Next?' The European Journal of International Law 23, no.3 (2012): 613.

14 Ibid, 614.

15 Thomas Heyd, Encountering Nature towards Environmental Culture (Hamphsire: Ashgate, 2007), 11.

16 Linda S. Bell, Andrew J. Nathan, and Ilan Peleg, Negotiating Culture and Human Rights (New York: Columbia University Press, 2001), 4.

17 Val Pulmwood, Op.Cit, 98.

18 Anthony Synnott, Re-Thinking Men: Heroes, Villains, and Victims, (New York: Routledge, 2009), 14,99 
shift from the nature of rights (nature as property or common concern) into the rights of nature (the environment has their right to exist). ${ }^{19}$ Therefore, to address this construction, this paper concluded that human rights conception per se is plain naïve in protecting environment based on this following series of explanation.

\section{Result and Discussion}

\subsection{Human Rights and Environmental Protection}

Historically, French Revolution engendered the Déclaration des droits de l'homme et $d u$ citoyen (1789) which could be said as the first authentic prescription of human rights context nowadays, in article II said as the purpose of any political alliance is to conserve the nature and rights of man. ${ }^{20}$ This principle impelled a strong sense of individualism, the rights of man per se referred to own liberty, property, security, and resistance to oppression. ${ }^{21}$ However, this is repudiated by naturalism approach that described man has no right to such property had been fathomed by Henry D Thoreau who depicted human relationship with natural life illustration that:

“...by avarice and selfishness, and a groveling habit, from which none of us is free, of regarding the soil as property, or the means of acquiring property chiefly, the landscape is deformed, husbandry is degraded with us, and the farmer leads the meanest of lives. He knows nature but as a robber." 22

He wanted to live deliberately in the woods and conveyed that the natural environment has its rights and human just acted to possess. Of course, the idea of capitalism turned things around, neither did the notion of universal human rights. Moreover, in Universal Declaration of Human Rights (UDHR) by United Nations which brings out the message of universalism, no single words are declaring the environmental rights (with affirmation) and environmental protection as regard which man can put in jeopardy on contrast. ${ }^{23}$ This could be understood historically that UDHR was created under the desperation of World War II cruelty and Nazi upon the racial atrocities ${ }^{24}$ as to why elicited such common understanding that human per se should be therefore protected, respected, and fulfilled. ${ }^{25}$

19 Susana Borràs, "New Transitions from Human Rights to the Environment to the Rights of Nature" Transnational Environmental Law 5.1 (2016):113-143.

20 Dale Van Kley, The French Idea of Freedom, the Old Regime and the Declaration of Rights of 1789 , (California: Stanford University Press, 1994), 1.

21 Ibid.

22 Henry David Thoreau, Walden or Life in the Woods, ed. Robert F. Sayre, (USA: Library of America, 1985), 124.

23 See UN General Assembly, Universal Declaration of Human Rights, Paris, 1948, http://www. un.org/en/universal-declaration-human-rights/.

24 John P. Humphrey, 'Memoirs of John P. Humphrey: The First Director of the United Nations Diviาsion of Human Rights,' Human Rights Quarterly 5, no.4 (1983): 387-439.

25 Jay Drydyk, 'Responsible Pluralism, Capabilities, and Human Rights' in Diane Elson, Sakiko Fukuda-Parr, and Polly Vizard, Human Rights and the Capabilities Approach: An Interdisciplinary Dialogue (New York: Routledge, 2012): 43. 
Later on, R. R Churchill tried to identify the existing of environmental rights which thus presumed as lex lata in some of major environmental rights embodiment began in the International Covenant on Civil and Political Rights (ICCPR/1966) and the European Convention on Human Rights (1950) that actually the environmental rights derived merely from rights to life, property, land, etc. ${ }^{26}$ In line with that, according to the United Nations on Environmental Programme, there are three primary legal dimensions of the relationship between human rights and environmental protection, they are: first, the environment as a precondition of full enjoyment of human rights, this further implies to States obligation to ensure the environmental protection in favour of fulfilling human rights. ${ }^{27}$ Second, environmental protection as procedural rights which endorse the value of information access, participation, access to justice in favour of environmental matters and decision-making. ${ }^{28}$ Third, the rights to environment as a human rights in it self ${ }^{29}$ which paid due scholarly attention to the ethical and legal debates.

At the point of departure, this concept could thus provide a bigger picture how the human rights efforts to engage in broader narratives in environmental protection both international and domestic law. Accordingly, the first study to scrutiny the relation between environmental degradation and human rights derived from the final report which was presented by Fatma Zohra Ksentini in 1994 that later offered the landmark of interconnectedness in between. ${ }^{30}$ To date, the new resolution adopted by the Human Rights Council on 24 March 2017 concerning Human Rights and the Environment, the progress is more of encouragement to states for taking human rights obligations and commitments into account in their efforts to protect the environment. ${ }^{31}$ According to Report of the Joint OHCHR-UNEP Meeting of Experts on Human Rights and the Environment dating back in 2002, the meeting agenda was careful to touch upon the complexities of how human rights law does not protect the environment explicitly or left the question whether the right to the environment is a substantive right. One of the thought-provoking statement made by Clapham and Dinah Shelton was the normative fact of the different approach in between; human rights is much of taking a remedial approach while the environ-

26 Alan Boyle and Michael Anderson (eds.), Human Rights Approaches to Environmental Protection, (Oxford: Clarendon Press, 1996), 90.

27 High Commissioner for Human Rights and United Nations on Environmental Programme, "Human Rights and the Environment, Rio+20: Joint Report OHCHR and UNEP" published on 19th June 2012, http://srenvironment.org/wp-content/uploads/2013/05/JointReportOHCHRandUNEPonHumanRightsandtheEnvironment.pdf accessed on 10 January 2018.

28 Alan Boyle, Op.Cit., 621.

29 Dinah L. Shelton, Human Rights and the Environment: Substantive Rights (2011) in Malgosia Fitzmaurice, David M. Ong and Panos Merkouris, (eds), Research Handbook on International Environmental Law (GWU: Legal Studies Research Paper, 2011), 2013-33.

30 UNHRC Annual Report Res. 19/34. 'Analytical Study on the Relationship Between Human rights and the Environment'. 16 Dec. 2011.

31 UNHRC Res. 34/20. "Human Rights and the Environment”. 24 Mar. 2017. 
mental protection emphasised the preventive and precautionary approach. ${ }^{32}$ This question seeks apparently a normative framework resolution but less considering the cultural discourses and discrepancy that it may encompass. Indeed, it is something new but will later impact in society through relativism and in doing so, is a paramount endeavour. Some prominent examples in this interdisciplinary legal-culture context are in the Ecuador Constitution that has put environmental protection as a substantive right and such as in the Article 24 African Charter on Human and People's Rights declared that "all people shall have the right to a satisfactory environment favourable to their development." 33

Therefore, this paper acknowledges that it is more important to know how human rights are defined within the environmental culture because this could be the significant reason to rejoinder the rudimentary human rights practice in challenging many environmental-related problems in the future (correcting of what is going wrong to our relationship with nature) ${ }^{34}$ as this may correlate to the question that reasoning about nature is too abstract for practical environmental policy-makers. In respect of examining the pivotal role of human rights in environmental protection, it is better to conceptually analyse it "in order for humans to respect the autonomy of nature itself, they must first understand the role of human culture in the shaping of the natural world"35 (or environmental culture).

\subsection{Why Environmental Culture?}

In examining the justification of human rights to protect the environment, we shall best come into the explanation from ground realities because the bottom-up approach is one of the alternative ways to capture the moral justifications of human rights present in practice, trying to explain its point from its legal practice. ${ }^{36}$ The concern is clear, that is to clarify the justifications of human rights in protecting the environment which is much needed in the first place ${ }^{37}$ to fulfil the pitfall of ecological crisis as same as what exactly the human 'environmental' rights are justifying, for examples in the human rights law or human rights as moral rights giving the pro tanto justification for forceful intervention. ${ }^{38}$

Hence, this paper put weigh in what account of the legal practice which engenders the human rights justification in the ecological crisis. Thus, the framework

32 Report of the Joint OHCHR-UNEP Meeting of Experts on Human Rights and the Environment (14-15 January 2002).

33 African (Banjul) Charter on Human and Peoples' Rights Adopted 27 June 1981, OAU Doc. CAB/ LEG/67/3 rev. 5, 21 I.L.M. 58 (1982), entered into force 21 October 1986).

34 Val Pulmwood, Op.Cit., 9.

35 Thomas Heyd, Op.Cit., 12.

36 Samantha Besson, Justification, in Daniel Moeckli, Sangeeta Shah, and Sandesh Sivakumaran (eds), International Human Rights Law (Oxford: Oxford University Press, 2014), 29.

37 Ibid, 23.

38 John Tasioulas, “Are Human Rights Essentially Triggers for Intervention?” Philosophical Compass 4, (2009), 940. 
of this writing is falling under the environmental culture as it clearly portrayed the ecological humanities more profoundly, that "resituate the human within the environment, and to resituate non-humans within cultural and ethical domains."39 We shall thus know the primary aim of the new development human rights instrument linking to the environmental matters, including the environmental rights and the emergence of the rights of environment discourse, is to simply protect the environment and broaden the scope of rights protection. ${ }^{40}$

Val Pulmwood began questioning the rationalisation towards the hyperseparation of human identity from nature ${ }^{41}$, conceptually we have separated ourselves from the natural environment. This can be seen through an earlier stage of international human rights law established that

puts human dignity and equality as main focus ${ }^{42}$ while human is deemed as inseparable units with the natural environment. This paper argues that the human denial of natural rights in the first place, made the rationalism generating, for instance 'wealth' as part of capitalist patriarchy derailed the concept of social justice and equality ${ }^{43}$ that brutally blindfolded the humanity which is deemed to be a cultural phenomenon, as Pulmwood deeply surmised. The environmental culture in this context is in conquering the nature-culture binary in which bring forward "the positions human outside of nature and thus implicitly posits that human hold the powerful to control their destiny within the natural world which is devoid of meaning, values, and the ethics." 44

In environmental culture, we could understand this problem through Gary Snyder statement, "the world of culture and nature, which is actual, ... is almost a shadow world now, and the insubstantial world of political jurisdictions and rarefied economies is what passes for reality." 45

As culture represents a prototype of human existence; the absence of a cultural association makes it arduous to create common identities and establish social values. ${ }^{46}$ While the complexity of environmental crisis nowadays simply reinvigorates the

39 Deborah Bird Rose, Thom van Dooren, Matthew Chrulew, Stuart Cooke, Matthew Kearnes and Emily O'Gorman, “Thinking through the Environment, Unsettling the Humanities" Environmental Humanities (2012): 1-5.

40 John G. Merrills, Environmental Rights in Daniel Bodansky, Jutta Brunnee, and Ellen Hey, International Environmental Law (Oxford: Oxford University Press, 2007), 667.

41 Val Pulmwood, Op.Cit, 8.

42 United Nations General Assembly Resolution 217 A, 'Preamble of Universal Declaration of Human Rights' 10 December 1948.

43 Maria Mies and Vandana Shiva, Ecofeminism (London: Zed Books, 2014),4.

44 Deborah Bird Rose, et al, Op.Cit, 3.

45 Patrick D. Murphy, Literature, Nature, and Other: Ecofeminist Critiques (New York: State University of New York Press, 1995), 147.

46 Javaid Rehman, "International Human Rights Law: A Practical Approach" (England: Pearson Education Limited, 2003), 123. 
ancient thoughts of 'ecological values' existences to human lives, and by contrast, the idea of phenomenal world has formulated the materialism to define what things are consisting of matter (real object), it seems that human sense-perceptions (experience) which Lange restated, “... is conditioned by an intellectual organisation which compels us to feel as we do feel, to think as we do think, while to another organisation the very same objects may appear quite different, and the thing in itself cannot be pictured by any finite being." ${ }^{77}$ This will enable us to overt the cognizance of the naïvenarratives as follows.

\subsection{The Naïveté Narratives}

\subsubsection{Naïveté}

Let us begin to understand what brings out the naïvete to clarify this supposition; the words 'Naïveté' has both philosophical and cultural meaning. As what Val Pulmwood rather like to use "environmental culture" because culture showed the way to concentrate on "...how deep, wide, and multi-levelled the cultural challenge must be to the systems that relate to us both materially and in terms of attitude and ideology to the ecologically world we all-too-unwittingly inhabit."48 Words Naïveté' also has a dualistic understanding as what human/nature binary has blindfolded the law positivism.

First, illustrated in Voltaire novel Candide, oul'Optimisme, which portrayed the Naïveté' through the human social condition that also coloured by religious blasphemy, satirical politic upheaval, and hostilities. ${ }^{49}$ Also, this novel gave rise to the optimism philosophical thinking that is similarly of no wisdom and being irrespective of sufficient knowledge which is put as follows:"It is demonstrable that things cannot be otherwise than as they are; for as all things have been created for some end, they must necessarily be created for the best end. Observe, for instance; the nose is formed for spectacles. Therefore, we wear spectacles." 50

This lines of 'nose are formed for spectacles' thereby gaining a Nä̈veté predicate. While nose is created not merely for glasses; more in-depth reason may lie upon other else. Indeed, it is the rejection of epistemological objectivism to why such nose should be created in a way it is. Human rights as discursive instrument showed the similarity when become reconciled to the practice in circumstances under the environmental culture. Human rights have evidently succeeded, looked at its origin and long history, against human subjection and subordination that conceived moral

47 Frederick Albert Lange, "The History of Materialism and Criticism of Its Present Importance", $1^{\text {st }}$ German Edition, (London: Lund Humphries, 1865), 158.

48 Val Pulmwood, Op.Cit., 4.

49 Ian Davidson, Voltaire in Exile, (New York: Grove Press, 2005), 53.

50 Hugo Grotius, The Classic of International Law, vol. II, Ed. James Brown Scott, (Oxford: Clarendon Press, 1925), 814. 
dimensions. However, human rights were not created to see the human as part of whole nature ${ }^{51}$, it was seen unwittingly otherwise. ${ }^{52}$ Arguably, this is the first mistake to view the needs for rights as only expressing the human preferences or interests ${ }^{53}$ in that time of needs.

Naïveté' could also express the sacred phrase of 'ecological denial', people shrug off the responsibility of knowing the truth especially in an environmental crisis that caused by human activities. ${ }^{54}$ In naïvete realism, this may point out that consciousness is experienced without reflective attitude, just dull acceptance. ${ }^{55}$ Having inspired by the human rights in 'righting' the environment, it seems the ideas should echo like this, as quoted in Robin Attfield "Do trees have rights? Only what is valuable in its own right has rights..."56 The current argument would be cynically thought that rights have no singularities of moral reasoning and it, therefore, does appear dissonant to delineate trees as a matter of justice. ${ }^{57}$ Put simply, the use of word naïve is a symbol of capturing the pragmatism rejection in favour of moral idealism that human rights protection achieved in respect of environmental protection.

\subsubsection{Do Human Rights Ignore the Intrinsic Environmental Values?}

There are two main assumptions established to answer the question, first, human rights in protecting environment is self-evident to meet the needs of humankind it self, even in the domains of the environmental rights which will entangle in accordingly, second, the realisation of environmental protection in human rights bodies frugally vindicated a naïveté scenario in contemporary discourse.

This paper viewed that human rights per se are justified by the human prudence ${ }^{58}$ which approached and strengthened by John Rawls, pretty akin to fairness, that is people need to secure their minimum standard of life as "each person claim primary goods as a matter of human right." ${ }^{59}$ Primary goods could be everything, included,

51 As Eleanor Roosevelt, the first chair of Human Rights Commission congratulated the Universal Declaration of Human Rights, the idea of environmental protection was missed. This was not because she forgot the environment, it is because the human rights instrument drafted before the dawn of modern environmental movement. John Knox in his keynote Speech at 2014 UNITAR-Yale Conference.

52 Val Pulmwood, The Feminism and the Mastery of Nature (London: Routledge, 1993), 172.

53 John G. Merrills, Op.Cit, 665.

54 David W. Orr and David Ehrenfeld, "None So Blind: The Problem of Ecological Denial," Conservation Biology 9, no. 5 (1995): 985-987.

55 Kenneth T. Gallagher, The Philosophy of Knowledge (California: Fordham University Press, 1962), 57.

56 John O'Neil, R. Kerry Turner, and Ian J. Bateman, Environmental Ethics and Philosophy, (Northampton: Edward Elgar Publishing, 2002), 345.

57 Ibid, 346.

58 James W. Nickel, Making Sense of Human Rights: Philosophical Reflections on the Universal Declaration of Human Rights (London: University of California Press, 1987), 85.

59 Briand Orend, Human Rights: Concept and Context (Canada: Broadview Press, 1971). 
rights to the health environment. Because there is no 'rights reasoning' narrative in environmental protection values, so it has not been possible to claim environmental issues without involving human rights in it. But in practice, the attempt to righting environment is eye-opening, away before the discursive point of human rights and environmental protection begin, the case of Sierra Club's legal battle to stop the development plan by Walt Disney Enterprises, Inc., in the Mineral King Valley of the Sierra Nevadas, could be initial precedent of rights reasoning joined the table of debates. It was Christopher D. Stone who used such case to illustrate the theory of natural objects, in themselves, should have rights before the law. Though the case ultimately lost, the Supreme Court of United States found an intriguing approach to the question: should trees have rights? ${ }^{60}$

In environmental culture, this may unravel the crisis of reason regarding the ecological crisis that we are currently facing for keeps. To give rise the alternatives that human rights broaden up its function, must now accentuate the environmental rights regime to riposte such environmental issues. In fact, the human rights consequently put the environment as an instrument. ${ }^{61}$ Furthermore, Diez et al., stated that "in measuring values to inform policy decisions, we have no direct way of assessing intrinsic value but have to rely on observations of human behaviour" ${ }^{62}$ We could only see the environment values depend on the human activities, this is naïve, on the other hand, it writes off other ecological beings and integral roles.

Historically, the rejection of basic ideas of natural rights (which we assumed the use of environmental rights are still referred to the basic naturalism) are championed by Jeremy Bentham, put simply that "natural rights is simple nonsense: natural and imprescriptible rights, rhetorical non-sense, non-sense upon stilts."63 Maurice Cranton, later refuted this stance, which said natural rights can be understood as universal moral rights, befall from the human rights claim naturally proposes. ${ }^{64}$ These debates are posited on actual depth understanding of human existence and others existential beings.

David E. Cooper used the Prometheans of Marx and Nietzche ideas to identify the human world, are not always analogous, but in the context of human world which based the ideas that "there is no discernable reality independent of human beings" and Marx wrote "Nature... taken... in its separation from man is nothing for

60 Christopher D. Stone, 'Should Tree Have Standing-Toward Legal Rights for Natural Objects', S. Cal. L. Rev 45 (1972):450.

61 Thomas Dietz, Amy Fitzgerald, and Rachael Shwom, 'Environmental values' Annual Review Environmental Resources 30 (2005): 335-372.

62 Ibid, 341.

63 Jeremy Bentham, Anarchical Fallacies; Being an Examination of the Declaration of Rights Issued during the French Revolution, republished in The Works of Jeremy Bentham, vol. II, ed. J. Bowring (Edinburgh: William Tait, 1843), 501.

64 Maurice Cranston, Op.Cit., 16. 
man", ${ }^{65}$ they showing agreement. Apparently, Marx tenably conjectured the universality or properties are 'anthropocentric'. Comparably, concept of man and nature in Asian philosophy are completely opposed the anthropocentric approaches, most of the literature put human in the central point of universe (part of environment), Graham Parkes (1989) summed up; as hereby stated in Lao-tzu 25, "Man models himself on earth, earth on heaven, heaven on the way, and the way on what is naturally so." There is the self-identification of being 'man' to how nature moves. Human beings are encouraged to be like water, thawing ice, uncarved wood, a valley, grass, and trees. ${ }^{66}$ This, for rationalist, will be repudiated as backwardness and non-sense. But Nietzsche ever suggested to invert "imaginatively" the human position now and went back to the primitive society to treasure the human relations to nature back then. ${ }^{67}$

Another great basic Asian philosophy can be found in Mahavakya Vedic in Chandogya Upanisad 6.8.7 that delineated the conversation between Uddalaka and his son Shvetaketu about the self and other existence by comparing environment elements such as trees, water, etc. ${ }^{68}$ One can be cited, "Even though we cannot see it, the Self is within all things, and there is nothing that doesn't come from Him. "This invisible and subtle essence is the Spirit of the whole universe. That is a reality. That is the truth. And you, Shvetaketu, you - are that!" 69

This depicted the essentialism as the fundamental basis for seeing the light of 'self in things', which has no definitive distinction. Like wise, in the Confucius values that approached more contextually human in social structure and ecological context, based on J. Baird Callicott who summarised that Confucius placed upon "a social model of human individuality which is an analogue of ecology's model of species adapting to niches in the economy of nature and thus acquiring their specific characteristics". ${ }^{70}$ In the latter, this unbolted the discourse between human and the nature that keep evolving in each relativism and shaping its foundation of argument.

\subsubsection{Legal Construction}

To make clear, Dinah Shelton fittingly deciphered the human rights, environmental rights, and the right to environment which displaying three main proposals:

65 David E. Cooper, The Measure of Things: Humanism, Humility, and Mystery, $1^{\text {st }}$ edition, (United States: Oxford University Press, 2002), 79.

66 J. Baird Callicott and Roger T. Ames, Nature in Asian Traditions of Thought, (Albany: State University of New York Press, 1989), 82.

67 David E. Cooper,Op.Cit.

68 Edwin Raphael, The Pathway of Non-duality, Advaitavada: An Approach to Some Key-Points of Gaudapada's Asparśavāda and Śamkara's Advaita Vedanta by Means of a Series of questions Answered by an Asparśin, (India: Philosophy Series. Motilal Banarsidass, 1992), 30.

69 Ibid.

70 J. Baird Callicott, "Conceptual Resources for Environmental Ethics in Asian Traditions of Thought: A Propaedeutic Source: Philosophy East and West”, Environmental Ethics 37, no. 2 (1987): 115-130. 
First, environmental problems may be combatted through the assertion of existing human rights, such as the rights to life, personal security, health, and food. In this regard, a safe and healthy environment may be viewed either as a pre-condition to the exercise of existing rights or as inextricably intertwined with the enjoyment of these rights. A second, intermediate position proposes a set of "environmental rights" (rights of the environment as well as rights to the environment) based upon existing rights to information about and involvement in the political decision-making process. Third and most ambitiously, a specific "right to environment" could be formulated and added to the current catalogue of human rights. ${ }^{71}$

Given that environmental agenda could not be fully accommodated in human rights instrument without deconstructing the concept of human rights and misshape such instrument, ${ }^{72}$ but one of the alternatives is to use the justification to play out in between the interplay Human Rights in the environmental values system, this regurgitation will inform us the needed course of action, ${ }^{73}$ such as applied in policy making and environmental security.

Environmental culture best reflects on how an anthropocentric logic structured the human self-enclosure that turns to be known as 'rationality' and this rationality has imprisoned multi-aspect of culture. ${ }^{74}$ As an example, the rights to a healthy environment as derived from the Principle 1 Rio Declaration which stands as soft law, the current international law instrument is vague at such whether the environmental policy will protect the environment or peoples' rights thereto. ${ }^{75}$ For examples, the financial development may require deforestation or industrial manufacturing development will inevitably dispose of the pollution, in a certain degree, this may affect the people. But as the protection of ecosystem per se lacks a human value or protection of people, then a rights-based approach to the protection of the environment would become problematic, unless, non-human values were inserted too in the system. ${ }^{76}$ As early mentioned, this paper argued what fundamental basis in this idea of a rights-based approach to the environment, is relied upon the prudential reasons which validate the prospect of people's good life, especially in their human ecosystem.

However, for that matter, as examples in Article 2 (1) of the International Convention on Economic, Social, and Cultural Rights (ICESCR/1966) foregrounded

71 Dinah Shelton, "Human Rights, Environmental Rights, and the Right to Environment", Stanford Journal of International Environmental Law 28 (1991): 105.

72 Ibid, 138.

73 Donald K. Anton, Dinah L. Shelton, Environmental Protection and Human Rights (New York: Cambridge University Press, 2011), 119.

74 Patsy Hallen, "Environmental Culture: The Ecological Crisis of Reason" (rev), Ethics and the Environment 7 , no. 2 (2002): 182 .

75 Ilias Bantekas and Lutz Oette, International Human Rights Law and Practice, $2^{\text {nd }}$ Edition, (United Kingdom: Cambridge University Press, 2016): 592.

76 C. Redgwell, "Life, Universe, and Everything: A Critique of Anthropocentric Rights", in A. Boyle and M. Anderson (eds.). Op.Cit., 71. 
the state obligation to realise economic social culture rights by making the maximum utilisation of their available resources. The maximum utilisation of a state's resources may provoke few critical purviews; this right partakes utilised-based ethics, which allows deliberately to the state to explore what they have or what it is defined as 'available resources'. The main problem begins in multifaceted aspect on social, economy, and cultural conjectures to what measurement is to address this phrase specifically. ${ }^{77}$ This is a second-rights generation that seemingly illustrates the contradictive thoughts in human rights that disregarded environmental protection and valued the natural object as an instrument in the first place.

From the case above, we conclude as the Barbara Rose Johnston stated:

"the abuse of human 'environmental' rights obviously occur within a cultural, as well as political, economic and biophysical context. Human environmental rights violations often occur as a result of efforts to gain control of land, labour, and resources of politically land/or geographically peripheral peoples. The cultural context involves a process of social construction, where marginal peoples are seen to be biologically, culturally, and socially inferior, justifying state domination."78

Furthermore, applying existing Human rights to environmental protection further can gape at some cases submitted to the court.In the industrial emissions and health behaviour of poor living people in the polluted area, Beatriz Mendoza $v$. The World, an individual led a class action filed a lawsuit against the government as well as 44 industrial polluters, which allegedly violated her constitutional right to a healthy environment. In 2006, the Supreme Court of Argentina commanded the authorities and the industry to fulfil the strict procedural remedies in the Matanza - Riachuelo River polluted areas. ${ }^{79}$ Another case studies pertaining the rights to healthy environment from the forest dwellers, the Minors Oposa v.Secretary of the Dept of Environmental and Natural Resources concerning the intergenerational environmental equity / rights in Philippines' deforestation of tropical forests that claimed "16 million hectares of rainforest twenty-five years prior to the suit, only 1.2 million had remained intact" 80 The notable principle that is recognised here regarding "the interdependence and indivisibility of rights' per se that the court approached in the civil and political rights since 'these basic rights need not even be written in the constitution for they are assumed to exist from the inception of humankind.' This aimed to protect the unborn or future generations amidst the forested-groups. ${ }^{81} \mathrm{In}$ the judgment of Marangopoulos Lignite $v$. Greece, showed that Greece was proven to

77 Ilias Bantekas and Lutz Oette, Op.Cit, 408.

78 Barbara Rose Johnston, "Human Rights and the Environment", Human Ecology 23, no 2, (1995): 115.

79 Beatrice Mendoza et al. v. State of Argentina et al. case concerning damages resulting from environmental pollution of Matanza/Riachuelo river, M. 1569. XL.

80 Ilias Bantekas and Lutz Oette, Op.Cit., 596.

81 Ibid. 
conduct non-compliance with the right to health under Article 11 of the European Social Charter regarding the air pollution in the area that has been found causal relations to many respiratory diseases. In which, the severe pollution found in the Eordea valley in Western Macedonia - Kozani and Florina prefectures, and the Megalopolis area in the Peloponnese - Arkadia prefecture, affected local people. ${ }^{82}$

Apparently, the definition of the environment through human rights that adopted in the international nor regional agreement is not fully-fledged. The definitive term of an environment is just merely concerned about human supporting units. The logical construction a priori that is touched off, as though, if the environment was destroyed and no human has found to be a victim, this need not be a claim. ${ }^{83}$ The international environmental laws hould be very critical to improve the environmental protection but on the other side, it lacks of stringent application compared to the human rights treaty bodies and its implicated compliances both in international and national. ${ }^{84}$ Therefore, the international law has to suffer the dilemma of notions of rights to healthy and ecologically sound environment ${ }^{85}$, let alone the self-standing approach in this rights bodies protection itself. The two international covenants referred to the right to a healthy environment in the context of the right to life. ICCPR, for instance, requires environment improvement for supporting the individual development or as fortified in ICESCR to measure the standard of health. ${ }^{86}$ Later, the Human Rights Committee emphasised the rights to life could precede the rights to healthy environment as such, where the protection of person life means that States should be obliged to take all possible measures to alleviate the infant mortality and otherwise to increase the life expectancy." As we could see, the legal construction remain impractical, not to mention the paradigm shift of identifying the rights of nature.

However, a review of a self-standing approach fell under national law instead, as undertaken in the Ecuador Constitution, "Wheeler c. Director de la Procuraduria General Del Estado de Loja, decided by a provincial court in Ecuador, was the first case in history to vindicate the constitutional rights of 'Pachamama' - often translated as "Mother Nature" as follows:88

82 Marangopoulos Foundation for Human Rights (MFHR) v. Greece, 26 ${ }^{\text {th }}$ April 2005, Collective Complaint No. 30/2005, Case Document 1.

83 Sumudu Atapattu, "The Right to a Healthy Life or the Right to Die Polluted? The Emergence of a Human Right to a Healthy Environment Under International Law", Tulane Environmental Law Journal 16, (2002): 65-126.

84 Laura Horn, "The Implications of The Concept of Common Concern of a Human Kind on a Human Right to a Healthy Environment", MqJICEL 1 (2004): 252.

85 Rebecca Bratspies, "Do We Need a Human Right to a Healthy Environment?", Santa Clara Journal of International Law 13, no. 1 (2015): 31-69.

86 See International Covenant on Civil and Political Rights, Art. 6 and International Covenant on Economic, Social and Cultural Rights, Art. 12.

87 UN Office of the High Commissioner for Human Rights, General Comment No. 6, 'The Right to Life (Article 6)', 16th Session, 30 Apr.1982, para. 5

88 Erin Daly, "The Ecuadorian Exemplar: The First Ever Vindications of Constitutional Rights of Nature" Review of European Community and International Environmental Law 21, no 1 (2012): 63. 


\section{Art.10 Rights Entitlement}

Persons and people have the fundamental rights guaranteed in this Constitution and in the international human rights instruments. Nature is subject to those rights given by this Constitution and Law. ${ }^{89}$

Art.71 Nature or Pachamama, where life is reproduced and exists, has the right to exist, persist, maintain and regenerate its vital cycles, structure, functions and its processes in evolution.

Every person, people, community or nationality, will be able to demand the recognitions of rights for nature before the public organisms. The application and interpretation of these rights will follow the related principles established in the Constitution. The State will motivate natural and juridical persons as well as collectives to protect nature; it will promote respect towards all the elements that form an ecosystem. ${ }^{90}$

This Constitutional Law even steps further for treating environmental as not only having the instrumental role but as constitutional and law subject, arguably this purified the intrinsic environmental values out of human-centeredness, rights recognised substantively and self-standing. As prescribed in Article 12 of the South African Constitution as well which stated that "everyone has the right (a) to an environment that is not harmful to their health or well-being, and (b) to have the environment protected..." 91 The indigenous people and other cultural communities have seriously played a significant political role in the country like Bolivia, for examples, they instituted Law of Mother Earth in 2010 were mainly rooted from their indigenous philosophies called Sumak Kawsay that emphasised the concept of harmony and nature as the central creation. ${ }^{92}$ But could it be said as constitutional pragmatism? Or simply Naïveté? Lalander has further introduced the contextualization.

In the stark contrast, in the international legal construction, invoke the environment has the substantive rights will surely meet a convoluted plot in the extraterritorial application, for examples. However, treating environment as conceived in procedural rights dimension, can be more applicable. As practiced in the 1998 Aarhus Convention, this convention may serve the environmental protection matters as supported in a way of the access of justice, information, and public participation, for example in the case Lopez Ostra $v$ Spain (1994) which denoted the "severe environmental pollution may affect individuals' well-being"93 and therefore this convention may

89 Political-economic II Rights Charter 1 Entitlement, Application, and Interpretation Principles of the Fundamental Rights, Constitution of The Republic of Ecuador National Assembly Legislative and Oversight Committee published in the Official Register 20 October 2008.

90 Tittle II Rights Chapter $7^{\text {th }}$ Rights of Nature, Constitution of the Republic of Ecuador.

91 The South African Constitution, Art.12.

92 Rickard Lalander, "Rights of nature and the indigenous Peoples in Bolivia and Ecuador: A Straitjacket for Progressive Development Politics?” Iberoamerican Journal of Development Studies 3, no. 2 (2014): 154.

93 Lopez Ostra v. Spain, 20 EHRR (1994) 277. 
enforce the existing human rights law to the impose the environmental protection obligation on States. ${ }^{94}$ In addition, this approach is currently the most possible in protecting the environment by the human rights instrument. As a result, in the case a quo, the European Court of Human Rights afforded the remedy for an environmental cause of action. ${ }^{95}$

Then, what is wrong with our human rights incorporating into the environmental matters? It is safe to say, currently naïve but it is not 'wrong' by radical means or even some said this is flawed. ${ }^{96}$ Actually, human rights are substantially based on rationalisation of human disembeddedness of his nature at the time that was born. Firstly, human rights have logical structure of centrism, the model of anthropocentrism as prior depicted. In this particular view point also showed that rationality pitfall that falls short the 'human rights' to embrace the intrinsic environmental values. Human Rights is an impure form of separation to its environment, this is merely creating, as Val Pulmwood always called, 'human-self enclosure'. As we are seeing nowadays, the dominant paradigm remains strong in which sadly, it is entrenched within this age of ecological crisis where the biosphere has no powerful standing themselves in human supremacy, given that they have all irreplaceability, non-exchangeability, and limits. ${ }^{97}$

Secondly, due to the doctrine conundrum of legal expansion in this concept, say, to generate the new catalogue of the environmental rights and rights to environment that appreciates the intrinsic environmental values is difficult or only officially understood is not enough, if the legal architecture remains unchanged. We can only refer it to numerous international human rights law which implicitly allows expanding such rights to be recognised even it is still under robust anthropocentric approach. For that matter, the 'expansive' right to environment is deemed to be a way of amplifying the environmental protection. ${ }^{98}$ Such as the rights to a healthy environment, now has shown a rapid pace of adoption in 177 of the world's 193 UN member nations as of 2012, "most countries recognise this right through their constitution, environmental legislation, court decisions, or ratification of an international agreement."99

According to the common objectives of human rights and environmental law, Dinah Shelton argued, the conflict of human and environment do not present in

94 Alan Boyle, Op.Cit, 622.

95 Luis E. Rodriguez-Rivera, "Is the Human Right to Environment Recognised under International Law? It Depends on the Source" Colorado Journal of International Environmental Law and Policy 12 no. 1, (2001): 7.

96 Luis E. Rodriguez-Rivera, Op.Cit, 4.

97 Val Pulmwood, Op.Cit, 120.

98 John H. Knox, “Climate Change and Human Rights Law”, Va. J. Int'l Law 50, no.1 (2009): 163.

99 David R. Boyd, "The Constitutional Right to a Healthy Environment" (2013) Law Now in relating law to life in Canada, [online] available at http://www.lawnow.org/right-to-healthy-environment/ accessed on 25 December 2017. 
such way (this paper examined in environmental culture), that is impossible to clearly separate the interest of humankind from environmental protection. ${ }^{100}$ Shelton added that to secure the intrinsic values of the biosphere is to understand that human is not viewed apart from or above the natural universe, but displaying an interdependency. ${ }^{101}$ This position closed to the objective of "human emancipation and fulfilment in an ecologically sustainable society." ${ }^{102}$ We also joined Shelton's argument, but this paper also further criticised, if this idea currently only brings forward naïveté, still lack of respect of environmental ethics and legal instrument, this can amount to legal pitfalls.

\section{Conclusion}

There is some conclusion we could present from this paper, as follows; first, we have to admit the significant complication of human rights and environmental protection in environmental culture lies in two reasoning, the prudential justification in this human right per se and the reliance of adequate legal umbrella. In the prudential rationale, human 'environmental' rights could only set apart the intrinsic environmental values, this will undeniably affect the foundation of policy making for further and the ecological denial of human embeddedness in nature only perpetuate the environmental crisis, neither do the environmental law nor human rights law may redress the ongoing problem. Unfortunately, the realisation of the hierarchical anthropocentricity that undermining the essence of nature is essentially deep-rooted in society, this imparts our current environmental culture.

In the other hand, the current legal architecture to satisfy the emergence of environmental rights / rights to environment could limitedly be applied pro tem. Nonetheless, the rights to healthy environment establishment need to be appreciated; many cases now take a lot of pluck to win the remedies and responsible measures to save the human ecosystem. As viewed in the case law, the practice is justifiable as a self-standing or corollary to other rights bodies. ${ }^{103}$ However, there are many legal could should raise in further contexts of environmental rights/rights to environment, such as is moral or legal rights?; who bears the rights, it either individual or groups?; Who bears the corresponding obligation to protect the environment?; or in the environmental ethics domain, "how are our obligations and responsibilities toward the natural world to be weighed against human values and interests?"104

100 Dinah Shelton, Op.Cit., 109.

101 Alexander Kiss and Dinah Shelton, International Law (Ardsley, New York: Transnational Publishers, 1991), 11 .

102 R. Eckersley, "Anthropocentric/Ecocentric Cleavage" in Julie Newman and Paul Robbins (Ed), Green Ethics and Philosophy: An A-to-Z Guide (USA: Sage, 2011), 106.

103 Ilias Bantekas and Lutz Oette, Op.Cit, 595.

104 Paul W. Taylor, Respect for Nature: A Theory of Environmental Ethics (New Jersey: Princeton University Press, 2011), 10. 
Second, in identifying the rights-based approach in environmental protection, we reaffirmed the human-centredness in environmental culture, and we share the explanation about how the cases jurisprudence clearly put the human in culture determinacy at stake. Indeed, the goal of this agenda is not the imposition of the eco-centric view, but thoroughgoing discourse, we, therefore, see the global change in a way we conceive of environmental protection, as "it is important to protect nature, but not under the blanket of protecting the human interest." ${ }^{105}$ In the latter, what is left is human-centred culture. The hegemonic above radical exclusion of human from other sentient beings or insentient is obvious.

The naïveté narratives here then construed a composition of explaining legal construction in environmental culture context which bridged by basic justification, human prudence. However, because the human rights in efforts to protect environment is still newborn (though officially understood) but still lacks of adequate theory support nor legitimation in the global plane, this is thus arguably naïve, especially tackling the current challenge in worst-off position, environmental destruction/ ecological limits by human and by the self-nature system. In other words, the environmental culture 'crisis of reason' remains perpetual through inadvertence of asserting this new rights regime. However, the rights expansionism, expanding future legal horizons is at the doorstep, as Ecuador, Bolivia, New Zealand take on the rights of nature in their domestic law as constitutional rights which this stems from the dialogue ethics between cultural localities that reframed the natural entities in the political state-making.

105 Susana Borràs, Op.Cit, 143. 


\section{BIBLIOGRAPHY}

\section{Book}

Albert Lange, Frerderick. The History of Materialism and Criticism of Its Present Importance. $1^{\text {st }}$ German Edition, London: Lund Humphries, 1865.

Anton, Donald K. and Dinah L. Shelton. Environmental Protection and Human Rights. New York: Cambridge University Press, 2011.

Bantekas, Ilias and Lutz Oette, International Human Rights Law and Practice, $2^{\text {nd }}$ Edition. United Kingdom: Cambridge University Press, 2016.

Bell, Linda S., Andrew J. Nathan, and Ilan Peleg. Negotiating Culture and Human Rights. New York: Columbia University Press, 2001.

Bentham, Jeremy, Anarchical Fallacies; Being an Examination of the Declaration of Rights Issued during the French Revolution, republished in The Works of Jeremy Bentham, vol. II, ed. J. Bowring. Edinburgh: William Tait, 1843.

Boyle, Alan E., and Michael R. Anderson. Human Rights Approaches to Environmental Protection. Oxford: Clarendon Press, 1996.

Callicott, J. Baird, and Roger T. Ames, eds. Nature in Asian Traditions of Thought: Essays in Environmental Philosophy. Albany: State University of New York Press, 1989.

Cooper, David E. The Measure of Things: Humanism, Humility, and Mystery, $1^{\text {st }}$ edition, United States: Oxford University Press, 2002.

Davidson, Ian. Voltaire in Exile. New York: Grove Press, 2004.

Thoreau, Henry David. "Walden; or, Life in the Woods, ed." FB Sanborn 2. 1985.

Fitzmaurice, Malgosia, David M. Ong, and Panos Merkouris, (eds). Research Handbook on International Environmental Law, GWU: Legal Studies Research Paper, 2011.

Gallagher, Kenneth T. The Philosophy of Knowledge. California: Fordham University Press, 1962.

Grotius, Hugo. The Classic of International Law, Vol. II, Ed. James Brown Scott. Oxford: Clarendon Press, 1925. 
Heyd, Thomas. Encountering Nature: Towards Environmental Culture. Hamphsire: Ashgate, 2007.

Kiss, Alexander and Dinah Shelton. International Law. New York: Transnational Publishers, 1991.

Mies, Maria and Vandana Shiva. Ecofeminism. London: Zed Books, 2014.

Murphy, Patrick D. Literature, Nature, and Other: Ecofeminist Critiques. New York: State University of New York Press, 1995.

Nickel, James W. Making Sense of Human Rights: Philosophical Reflections on the Universal Declaration of Human Rights. London: University of California Press, 1987.

O'Neil, R. John, Kerry Turner, and Ian J. Bateman, Environmental Ethics and Philosophy. Northampton: Edward Elgar Publishing, 2001.

Orend, Briand. Human Rights: Concept and Context. Canada: Broadview Press, 2002.

Plumwood, Val. Environmental Culture: The Ecological Crisis of Reason. $1^{\text {st }}$ ed. New York: Routledge, 2002.

Plumwood, Val. The Feminism and the Mastery of Nature. London: Routledge, 1993

Rehman, Javaid. “International Human Rights Law: A Practical Approach”, England: Pearson Education Limited, (2003).

Raphael, Edwin. The Pathway of Non-duality, Advaitavada: An Approach to some Key-points of Gaudapada's Asparśavāda and Śamkara's Advaita Vedanta by Means of a Series of Questions Answered by an Asparśin. Iia: Philosophy Series Motilal Banarsidass, 1992.

Synnott, Anthony. Re-Thinking Men: Heroes, Villains, and Victims. New York: Routledge, 2009.

Taylor, Paul W. Respect for Nature: A Theory of Environmental Ethics. New Jersey: Princeton University Press, 2011.

Van Kley, Dale. The French Idea of Freedom, the Old Regime and the Declaration of Rights of 1789. California: Stanford University Press, 1994.

\section{Chapter or other part of an edited book}

Besson, Samantha, "Justification." In International Human Rights Law, edited by Daniel Moeckli, Sangeeta Shah, and Sandesh Sivakumaran, Oxford: Oxford University Press, 2014. 
Drydyk, Jay. "Responsible Pluralism, Capabilities, and Human Rights." In Human Rights and the Capabilities Approach: An Interdisciplinary Dialogue, edited by Diane Elson, Sakiko Fukuda-Parr, and Polly Vizard. New York: Routledge, 2012.

Eckersley, R. "Anthropocentric/Ecocentric Cleavage." In Green Ethics and Philosophy: An A-to-Z Guide, edited by Julie Newman and Paul Robbins. USA: Sage, 2011.

Merrills, John G. "Environmental Rights." In International Environmental Law, edited by Daniel Bodansky, Jutta Brunnee, and Ellen Hey. Oxford: Oxford University Press, 2007.

Shelton, Dinah L. "Human Rights and the Environment: Substantive Rights. In Research Handbook on International Environmental Law edited by Malgosia Fitzmaurice, David M. Ong and Panos Merkouris. GWU: Legal Studies Research Paper, 2013.

Redgwell, C. "Life, Universe, and Everything: A Critique of Anthropocentric Rights." In Human Rights Approaches to Environmental Protection, edited by A. Boyle and M. Anderson. Oxford: Clarendon Press, 1996.

\section{Journal Article}

Atapattu, Sumudu. 'The Right to a Healthy Life or the Right to Die Polluted? The Emergence of a Human Right to a Healthy Environment Under International Law.' Tulane Environmental Law Journal 16, no.1 (2002): 65-126. Chapter or other part of an edited bookLaw." Tulane Environmental Law Journal 16, no. 1 (2002): 65-126. http://www.jstor.org/stable/43292777.

Borràs, Susana. "New Transitions from Human Rights to the Environment to the Rights of Nature." Transnational Environmental Law 5, no. 1 (2016): 113-143. https:/ / doi.org/10.1017/S204710251500028X

Boyle, Alan. "Human Rights and the Environment: Where Next?." European Journal of International Law 23, no. 3 (2012): 613-642. https://doi.org/10.1093/ejil/ chs054

Bratspies, Rebecca, “Do We Need a Human Right to a Healthy Environment?”, Santa Clara Journal of International Law 13, no. 1 (2015): 31-69.

Callicott, J. Baird. "Conceptual Resources for Environmental Ethics in Asian Traditions of Thought: A Propaedeutic." Philosophy East and West 37, no. 2 (1987): 115-30. doi:10.2307/1398732.

Daly, Erin. "The Ecuadorian Exemplar: The Firstever Vindications of Constitutional Rights of Nature." Review of European, Comparative \& International Environmental Law 21, no. 1 (2012): 63-66. https://doi.org/10.1111/j.1467-9388 $.2012 .00744 . \mathrm{x}$ 
Dietz, Thomas, Amy Fitzgerald, and Rachael Shwom. "Environmental values." Annual. Review Environmental Resources. 30 (2005): 335-372. https://doi. org/10.1146/annurev.energy.30.050504.144444

Galizzi, Paolo. "From Stockholm to New York, via Rio and Johannesburg: Has the Environment Lost its Way on the Global Agenda." Fordham Int'l $L J$ 29, no. 5 (2005): 952-1008.

Hallen, Patsy. "Environmental Culture: The Ecological Crisis of Reason" (rev), Ethics and the Environment 7, no. 2, (2002): 181-184. http://www.jstor.org/ stable/40339041.

Horn, Laura. "The Implications of the Concept of Common Concern of a Human Kind an a Human Right to a Healthy Environment." Macquarie J. Int'l \& Comp. Envtl. L. 1 (2004): 233-268.

John P. Humphrey, 'Memoirs of John P. Humphrey: The First Director of the United Nations Divi $\neg$ sion of Human Rights,' Human Rights Quarterly 5, no.4 (1983): 387-439.

Johnston, Barbara Rose. "Human Rights and the Environment," Human Ecology 23, no. 2 (1995): 111-123.

Knox, John H. "Climate Change and Human Rights Law", Va. J. Int'l Law 50, no.1 (2009):163-218.

Lalander, Rickard. "Rights of Nature and the Indigenous Peoples in Bolivia and Ecuador: A Straitjacket for Progressive Development Politics?", Iberoamerican Journal of Development Studies 3 No. 2 (2014):148-173. http:/ /dx.doi.org/10.2139/ssrn. 2554291

Orr, David W. and David Ehrenfeld. "None So Blind: The Problem of Ecological Denial." Conservation Biology 9, no. 5 (1995): 985-987. http://www.jstor.org/ stable/2387037.

Rodriguez-Rivera, Luis E. "Is the Human Right to Environment Recognised under International Law? It Depends on the Source", Colorado Journal of International Environmental Law and Policy 12, no 1 (2001):1-45.

Rose, Deborah Bird, Thom van Dooren, Matthew Chrulew, Stuart Cooke, Matthew Kearnes, and Emily O'Gorman. "Thinking through the environment, unsettling the humanities." Environmental Humanities 1, no. 1 (2012): 1-5.

Shelton, Dinah. "Human Rights, Environmental Rights, and the Right to Environment", Stanford Journal of International Environmental Law 28, (1991):103-138.

Stone, Christopher D. "Should Trees Have Standing-Toward Legal Rights for Natural Objects.” S. Cal. l. rev. 45 (1972): 450-501. 
Tasioulas, John. "Are Human Rights Essentially Triggers for Intervention?." Philosophy Compass 4, no. 6 (2009): 938-950. http://dx.doi.org/10.1111/j.1747-9991 .2009.00246.x

\section{International Instruments}

African (Banjul) Charter on Human and Peoples' Rights Adopted 27 June 1981, OAU Doc. CAB/LEG/67/3 rev. 5, 21 I.L.M. 58 (1982), entered into force 21 October 1986.

United Nations Conference on Environment and Development, Rio Declaration on Environment and Development. UN Doc. A/CONF.151/26 (vol. I); 31 ILM 874 (1992).

United Nations General Assembly, Declaration of the United Nations Conference on the Human Environment, U.N. Doc. A/Conf.48/14/Rev. 1(1973); 11 ILM 1416 (1972).

United Nations General Assembly, International Covenant on Economic, Social and Cultural Rights, 16 December 1966, United Nations, Treaty Series, vol. 993.

United Nations General Assembly, International Covenant on Civil and Political Rights, 16 December 1966, United Nations, Treaty Series, vol. 999.

United Nations General Assembly Resolution 217 A, Universal Declaration of Human Rights, 10 December 1948.

United Nations. Report of the United Nations Conference on the Human Environment. A/CONF.48/14/Rev.1.

United Nations. Report of the Joint OHCHR-UNEP Meeting of Experts on Human Rights and the Environment (14-15 January 2002).

Human Rights Council (UNHRC). res. 16/11, Human Rights and the Environment. 24 Mar. 2011.

Human Rights Council (UNHRC). res. 19/12. Human Rights and the Environment. 20 Mar. 2012.

Human Rights Council (UNHRC). res. 34/20. Human Rights and the Environment' 24 Mar. 2017.

Human Rights Council (UNHRC). Report of United Nations Independent Expert on human rights and the environment with the Office of the High Commissioner for Human Rights. 21-22 June 2013.

Human Rights Council (UNHRC). Annual Report Res. 19/34. Analytical Study on the Relationship Between Human Rights and the Environment. 16 Dec. 2011. 
United Nations Office of the High Commissioner for Human Rights (OHCHR), General Comment No. 6, 'The Right to Life (Article 6)', 16th Session, 30 Apr.1982.

\section{Website Content}

Boyd, David R. "The Constitutional Right to a Healthy Environment" (2013) Law Now in relating law to life in Canada, [online] available at http://www.lawnow. org/right-to-healthy-environment/ accessed on 25 December 2017.

Hansen, James E., "Amicus Curiae Brief Petition Requesting for Investigation of the Responsibility of the Carbon Majors for Human Rights Violations or Threats of Violations Resulting from the Impacts of Climate Change, Commissioners, Commission on Human Rights of the Philippines' published on 16th December 2016, https://business-humanrights.org/sites/default/files / documents / 2017.08.28_Jim.Hansen.Amicus_Comm_Human\%20Rights_0.pdf accessed on 12 February 2018.

High Commissioner for Human Rights and United Nations on Environmental Programme, "Human Rights and the Environment, Rio+20: Joint Report OHCHR and UNEP” published on 19th June 2012, http://srenvironment.org/ wp-content/ uploads /2013/05/JointReportOHCHRandUNEPonHumanRightsandtheEnvironment.pdf accessed on 10 January 2018.

\section{Cases Law}

Beatrice Mendoza et al v. State of Argentina et al Case Concerning Damages Resulting from Environmental Pollution of Matanza/Riachuelo river, M. 1569. XL.

EHP v Canada (Communication No. 67/1980) (1982) 33.

Lopez Ostra v. Spain, 20 EHRR (1994) 277.

Marangopoulos Foundation for Human Rights (MFHR) v. Greece, 26th April 2005. Collective Complaint No. 30/2005. Case Document 1.

Maya indigenous v. Belize, Case 12.053, Report No. 40/04, Inter-Am. C.H.R., OEA/ Ser.L/V/II.122 Doc. 5 rev. 1 at 727 (2004).

Önery1ldız v Turkey, App no 48939/99, ECHR 2004-XII, (2005). 